\title{
LAND SUITABILITY BASED ON SPECIFIC LOCATIONS FOR SAGO PALM (METROXYLON SP.) IN RAINFED DRYLANDS IN THE SALU PAKU SUB-WATERSHED, THE RONGKONG UPSTREAM WATERSHED, NORTH LUWU REGENCY OF SOUTH SULAWESI, INDONESIA
}

\author{
Yumna* \\ Doctoral Program of Agricultural Science, Faculty of Agriculture, University of Brawijaya, \\ Indonesia
}

Prijono Sugeng, Kusuma Zaenal, Soemarno

Faculty of Agriculture, University of Brawijaya, Indonesia

*E-mail: yumnaunanda@yahoo.com

\begin{abstract}
This research aims to describe the characteristics of sago plantations and sago development plans, analyze land suitability for sago by considering site-specific conditions and determine suitability classes of S1/highly suitable, S2/moderately suitable, S3/marginally suitable, and $\mathrm{N} /$ not suitable, and evaluate suitability classes for sago development in the Salu Paku subwatershed. The land was evaluated in detail based on elevation and slope. The land evaluation procedure employed the matching method. Land characteristics identified were rainfall, humidity, temperature, sunshine, solar radiation, drainage conditions, soil texture, root depth, optimal $\mathrm{pH}$ and C-Organic, bulk density, and moisture content. Site-specific land suitability criteria indicate that temperatures $>29^{\circ} \mathrm{C}$ are not optimal for sago production in general, but are still optimal for local sago (production of $210.5-560.89 \mathrm{~kg} / \mathrm{tree}$ ). Actual suitability analysis results show that the Salu Paku sub-watershed has a moderately suitable (S2) area of $1,889.61$ ha and a not suitable $(\mathrm{N})$ area of 440.24 ha. Suitability classes can be upgraded to potential suitability classes from S2 to $S 1$ (116.95 ha) and N to S2 (437.89 ha). The limiting factors in land units (S2) are water content, C-organic, bulk density, and temperature. An input to improve land suitability is through water management by increasing groundwater through an increase in infiltration capacity by making terraces, ponds, and dead-end trenches.
\end{abstract}

\section{KEY WORDS}

Land suitability, land use, hydrology, soil properties, elevation, land characteristic, watershed.

The Food and Agriculture Organization (FAO) projected world population to increase from seven billion in 2010 to nine billion in 2050 (Gerland et al., 2014; Girsang, 2018). Rapid population growth has an impact on per capita food consumption increase (Konuma, 2018). Global food demand will increase as well (Bernes-Lee et al., 2018) and is estimated to increase by $60-70 \%$ (Henry et al., 2018; Girsang, 2018). Population growth and food security are challenges for human development in the world (Singhal et al., 2008; Tomlinson, 2013), especially in developing countries (Prosekov \& Ivanova, 2018) such as Indonesia. These issues encourage policymakers, scientists, and industry players to actively search for alternative food sources. Some researchers have high hopes for sago (Metroxylon spp) in responding to the global food crisis (Yamamoto, 2018; Suyastri et al., 2018). Indonesia contributes to 55 percent of the world's sago (Kurnia, 2017).

Indonesia has quite high potential for sago (Konuma, 2018). Sago land areas reach 219,978 ha with a productivity of 2.23 tons/ha/year. The main distributions of sago land areas in Indonesia are Maluku, Papua, Sulawesi, Sumatra, and Kalimantan. Most areas of sago are natural forests of around 1,067,590 ha (90.3\%) and traditionally cultivated or semicultivated sago areas of only around 114,000 ha (9.7\%) (Budianto, 2003 in Manaroinsong et 
al., 2018). South Sulawesi has a potential sago area (10,000 ha), but only 4,383 ha has been used with low productivity of 0.60 tons/ha/year (The Estate Crop Statistics of Indonesia, 2017). The Indonesian Sago Utilization Association said that national sago production is around 489,643 tons per year, while the need for sago flour is around 1 million tons per year (Food Security Agency of the Ministry of Agriculture, 2018). The data is an indicator of sago development in Indonesia.

Sago habitat is still predominantly in natural forests and grows in wetlands such as river banks and muddy lands (Botanri et al. (2011), marsh and peat soils (Mofu et al., 2005), and freshwater swamps (Flach, 1997; McClatchey et al., 2006; Ehara, 2005). Habitat conditions influence sago growth and sago productivity (Azhar et al., 2018). Botanri et al. (2011) examined differences in sago plants growing in drylands and wetlands and showed that sago production is higher in drylands. Sago production in drylands can reach 343 $\mathrm{kg} / \mathrm{tree}$, whereas wetlands (submerged roots) produce an average of $125 \mathrm{~kg} / \mathrm{tree}$ (Leuhenapessy, 1996). Low production per tree will reduce sago productivity. Photosynthesis influence this condition. Photosynthetic capacity is higher in drylands than in wet and inundated lands (Azhar et al., 2018) because stagnant lands cause a decrease in chlorophyll (Vu and Yelenosky, 1991). Sago plant growth is faster in drylands, causing it to be more capable of utilizing sunlight for metabolism (Flach, 1991). Metabolic processes are more inhibited in stagnant lands because high $\mathrm{pH}$ (Alkaline) inhibits the formation of trunks and leaves (Flach and Schuiling, 1988). Low sago productivity in stagnant lands is the effect of tiller dominance. Sago plants dominated by seedlings and tillers have a very high failure rate (85\%) to form stems (Botanri et al., 2011).

Sago land area of $1,453.08$ ha in the Rongkong watershed is mostly distributed in lowland wetlands (downstream part of the watershed). The average productivity is $1,917.45$ $\mathrm{kg} / \mathrm{ha}$ per year (Department of Food Crops, Horticulture, and Plantations of North Luwu, 2017). The data shows that if one sago tree has an average of $200 \mathrm{~kg} / \mathrm{tree}$ of sago starch (sago farmer survey results), it means that only about 10 stems per ha per year reach productive age. This number is very low when compared with Botanri et al.'s (2011) identification results for sago in drylands in Seram Maluku $(578.74 \mathrm{~kg} / \mathrm{tree})$. The ideal condition of sago productivity is 20-25 tons/ha (Ahmad, 2014; Leomo et al., 2016). Based on the guidelines for the cultivation of sago palm, with a planting distance of 10 meters in 1 ha, ideally there will be 100 sago trees per period reaching the mature phase. It indicates that very few sago trees growing in the Rongkong watershed reaches the mature phase, generally dominated by the seedling and sapling phases.

Sago extensification is an effort to increase productivity. Extensification means the expansion of sago land area in rainfed drylands of the Rongkong upstream watershed, precisely in the Salu Paku sub-watershed. Sago palm cultivation will improve soil conditions, while at the same time respond to the environmental problems in the Rongkong River Basin, i.e. periodic flood events. The research results of the Integrated Rongkong Watershed Management Plan showed that floods occur every year and major floods occur every ten years. The recent data showed major floods occurred in June 2018. Floods in the downstream part of the Rongkong watershed are caused by a combination of high rainfall and watershed morphology. The Rongkong watershed is located in the highlands and dominated with steep and very steep slopes (70\%). The Salu Paku sub-watershed is the upstream part of the Rongkong watershed. This area contributes to downstream water and erosion (Saddang Watershed Management Center, 2011). These problems can be minimized by planting sago because sago has a fibrous root system. The fibrous root system has the potential to absorb and store water in rainfed areas. Consideration of productivity and environmental improvement in the watershed is a strong reason to plant sago in rainfed highlands in the Rongkong upstream watershed.

Bintoro (2008) stated that sago can grow well at an elevation of $400 \mathrm{~m}$ above sea level, even at an elevation of $700 \mathrm{~m}$ above sea level to $1000 \mathrm{~m}$ above sea level (Flach, 1977). However, the research results are still too general to be applied to the research location. Data has not shown land characteristics and suitability in detail at every change in elevation. Sago planting plans in these land conditions require more detailed data support on the 
characteristics of the Salu Paku sub-watershed, the Rongkong upstream watershed, North Luwu Regency. Sago growth requirements (Bintoro, 2018) which form the basic criteria of land suitability in several classes are still general. Site-specific criteria are important because sago in the research location is different from other regions. Land characteristics also vary regarding sago growth, so data on some local sago plantations are needed. Detailed data is also obtained by identifying land characteristics in land units by considering the topography (elevation and slope).

This research aims to 1) describe sago growth requirements and sago plantation characteristics in South Sulawesi, 2) compile site-specific criteria for sago land suitability by considering sago growth requirements and local sago plantation characteristics, 3) describe land characteristics of rainfed drylands in the Salu Paku sub-watershed, the Rongkong upstream watershed, North Luwu Regency, and 4) analyze the level of land suitability for rainfed dryland sago plantations in the Salu Paku sub-watershed, the Rongkong upstream watershed based on site-specific criteria. The analysis results become a reference in developing a rainfed dryland sago management strategy.

\section{METHODS OF RESEARCH}

Research locations included several administrative areas (Luwu Regency, Palopo City, and North Luwu Regency, South Sulawesi). The research location of land characteristics for sago development plans focused at the Salu Paku sub-watershed in the Rongkong upstream watershed, Sabbang District, North Luwu Regency. The Salu Paku sub-watershed was chosen as the research location because it contributed greatly to the Rongkong watershed performance. The Salu Paku sub-watershed has an area of 13,626 ha $(21.7 \%$ of the Rongkong watershed area) which is geographically located at $2^{\circ} 37^{\prime} 0^{\prime \prime}-2^{\circ} 42^{\prime} 0^{\prime \prime}$ South Latitude and $119^{\circ} 55^{\prime} 0^{\prime}-120^{\circ} 6.5^{\prime} 0^{\prime \prime}$ East Longitude. This area consists of several elevation variations ranging from $201 \mathrm{~m}$ above sea level to $>1000 \mathrm{~m}$ above sea level (Figure 1).

Soil sampling was done intentionally on all land units. The elevation map overlay with slope maps produced 23 land units (Figures 1 and 2). Sampling prioritized shrub cover, mixed gardens, and rice fields. Forest condition is still tightly closed so it is not the target of sago land development plans. Land units as sampling areas consisted of 23 units/areas, i.e.: Area 1; 201-300 m MSL with flat condition (12.50 ha), Area 2; 201-300 m MSL with sloping condition (3.42 ha), Area 3; 201-300 m MSL with rather steep condition (13.32 ha), Area 4; 201-300 m MSL with steep condition (1.78 ha), Area 5; 201-300 m MSL with very steep condition (1.11 ha), Area 6; 301-400 m MSL with flat condition (55.17 ha), Area 7; 301-400 m MSL with sloping condition (45.86 ha), Area 8; 301-400 m MSL with rather steep condition (105.65), Area 9; 301-400 m MSL with steep condition (36.74 ha), Area 10; 301-400 m MSL with very steep condition (1.20 ha), Area $11 ; 401-500 \mathrm{~m}$ above sea level with flat condition (60.91 ha), Area 12; 401-500 m MSL with sloping condition (103.61 ha), Area 13; 401-500 m MSL with rather steep condition (229.87 ha), Area 14; 401-500 m MSL with steep condition (99.43 ha), Area 15; 401-500 m MSL with very steep condition (0.04 ha), Area 16; 501-600 m MSL with flat condition (35.26 ha), Area 17; 501-600 m MSL with sloping condition (151.63 ha), Area 18; 501-600 m MSL with rather steep condition (378.47 ha), Area 19; 501-600 m MSL with steep condition (131.65 ha), Area 20;601-700 m MSL with flat condition (32.72 ha), Area 21; 601-700 m MSL with sloping condition (191.89 ha), Area 22; 601-700 m MSL with rather steep condition (469.33 ha), and Area 23; 601-700 m MSL with steep condition (168.29 ha). Area designation took into account the maximum elevation requirements for sago of 0-700 m MSL (Bintoro, 2018). Soil samples were taken in three layers, i.e. the 0-30 $\mathrm{cm}, 30-60$, and $60-100 \mathrm{~cm}$ layers. The profile depth was determined based on the depth of the dry land sago plant of about $85 \mathrm{~cm}$ (Flach, 1997).

Soil samples were analyzed at three institutions, i.e. the Soil Physics Laboratory, Faculty of Agriculture, Hasanuddin University, Makassar, the Soil Physics Laboratory, Brawijaya University, Malang, and the Soil Mechanics Laboratory, Andi Djemma Palopo University. Soil properties analysis included Bulk Density, $\mathrm{pH}, \mathrm{C}$-organic, texture, and moisture content. Bulk Density was determined using cylinder method, soil pH was 
determined using a $\mathrm{pH}$ meter, C-organic was determined using the Walkley-Black Method, texture was determined using the Hydrometer Method, moisture content was determined using the Gravimetric Method, and salinity was determined using the Electrical Conductivity Method. Data collection on soil properties was technically based on guidelines set by Bogor Soil Research Institute (2005).

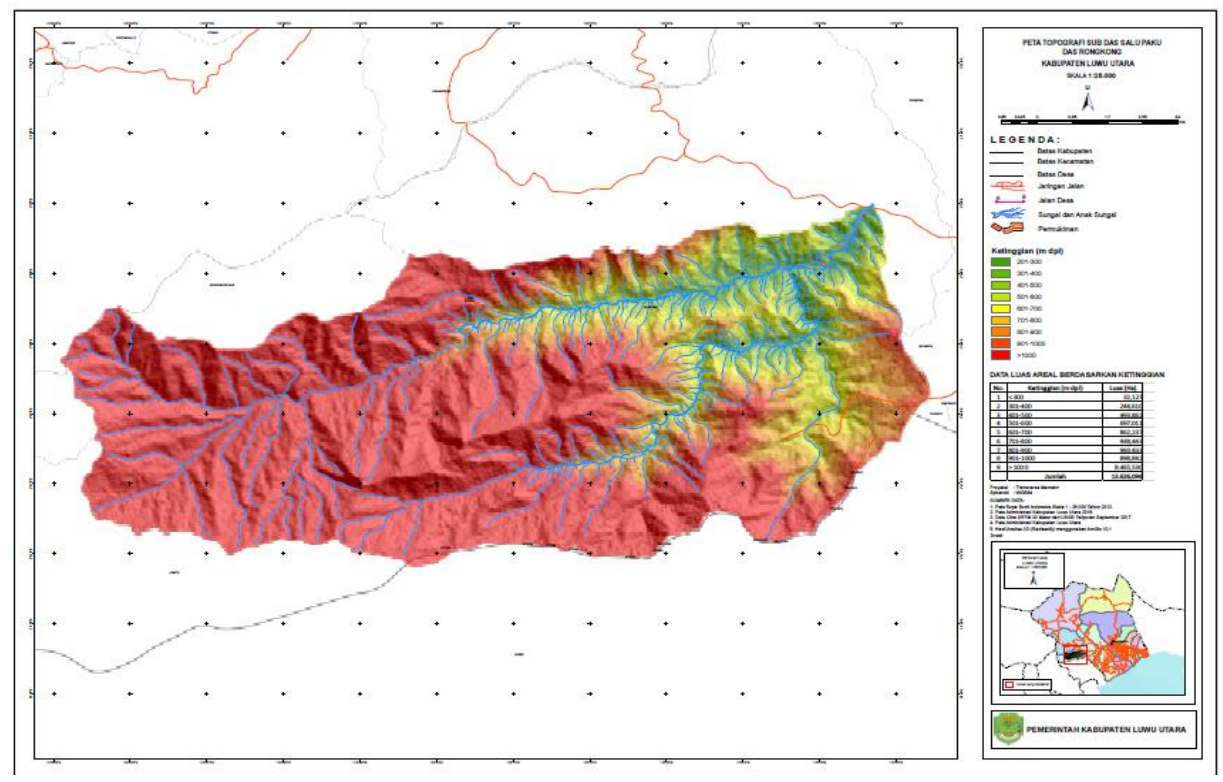

Figure 1 - The elevation map of the Salu Paku sub-watershed

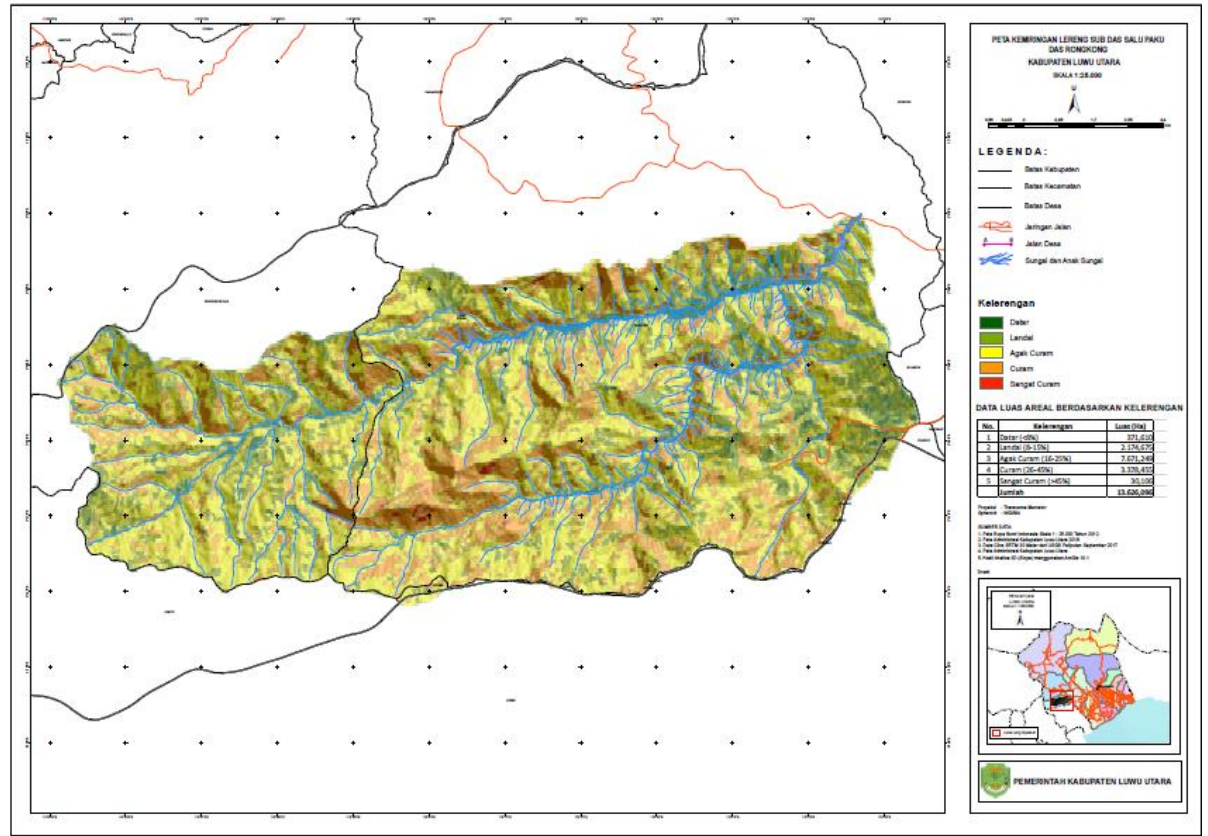

Figure 2 - The slope map of the Salu Paku sub-watershed

Sago growth requirements as a reference were obtained through literature review (field test results by previous researchers i.e. Flach, 1997; Leuhenapessy, 2010; Bintoro, 2018; Nusawakan et al, 2017; Haeruddin, 2018) and compiled with local sago land characteristics data (survey results of sago lands in Palopo City, Luwu Regency, and North Luwu Regency, 2018) and interviews with sago farmers. Compilation results determined the suitability criteria for site-specific sago lands. Land suitability criteria were decided based on the production index expressed in percentages of optimal production, i.e. highly suitable/S1 (> $80 \%$ of 
optimal production), moderately suitable/S2 (60-80\%), marginally suitable/S3 (40-59\%), and Not suitable/N (<40\%), based on the FAO Framework (1983). Land suitability assessment used the matching method between land characteristics and site-specific land suitability criteria (Rossister, 1996; Girmay et al., 2018) and determination of suitability classes based on limiting factors.

\section{RESULTS AND DISCUSSION}

Sago growth requirements are presented in Table 1. Identification results of land characteristics in some sago plantations in South Sulawesi (2018 survey) are presented in Table 2 while identification results of land characteristics in some sago plantations in the Rongkong watershed (2018 survey) are presented in Table 3.

Table 1 - Metroxylon sp. growth requirements for optimal growth and production (Bintoro, 2014; Leuhenapessy, 1996; Flach, 1997)

\begin{tabular}{|c|c|c|}
\hline No. & Land Characteristic & Sago (Metroxylon sp.) growth requirements \\
\hline \multicolumn{3}{|c|}{ A. Hydrology/Climate: } \\
\hline 1. & Rainfall & $2000-4000 \mathrm{~mm} /$ year \\
\hline 2. & Humidity & $40-90 \%$ \\
\hline 3. & Total dry months & Max 2 months in a row \\
\hline 4. & Total wet months & $4-9$ months in a row \\
\hline 5. & Total rainy days & 142 - 209 days per year \\
\hline 6. & Average temperature & $15^{\circ}-29^{\circ} \mathrm{C}$ \\
\hline 7. & Solar radiation & quite high $\left(900 \mathrm{~J} \mathrm{~cm}^{-2}\right.$ day-1) \\
\hline 8. & Drainage & Very good - very bad \\
\hline \multicolumn{3}{|c|}{ B. Land and Soil Properties: } \\
\hline 1. & Topography & flat until bumpy \\
\hline 2. & Rock material & $0-30 \%$ \\
\hline 3. & $\mathrm{pH}$ & $3.5-6.5$ \\
\hline 4. & C-Organic & $0-30 \%$ \\
\hline 5. & Salinity & No salinity \\
\hline 6. & Texture & $\begin{array}{l}\text { broad-spectrum ranging from the soil with clay composition }>70 \% \text { to sandy (all classes of } \\
\text { texture (clay - sandy) }\end{array}$ \\
\hline & Ground color & black, brown, red, gray \\
\hline C. P & $\begin{array}{l}\text { duction: } \\
\text { Optimal Production }\end{array}$ & 200 - >400 kg/tree (2-4 tons/ha) \\
\hline
\end{tabular}

Source: Secondary data (literature review).

Table 2 - Land Characteristics of Sago Plantations in Luwu Regency and Palopo City, South Sulawesi (2018)

\begin{tabular}{|c|c|c|c|}
\hline No. & Land Characteristic & Area I & Area II \\
\hline \multicolumn{4}{|c|}{ A. Land Shape: } \\
\hline 1. & Elevation (m MSL) & $90-500$ & $0-15$ \\
\hline 2. & Slope & ramps - very steep & ramps - flat \\
\hline \multicolumn{4}{|c|}{ B. Climate: } \\
\hline 1. & Rainfall (mm/year) & $1067-3768$ & 2110 \\
\hline 2. & Average temperature $(\mathrm{C})$ & $15-23$ & $25-30$ \\
\hline 3. & Dry months (months) & $2-3$ & $2-3$ \\
\hline 4. & Wet months (months) & $6-7$ & $6-7$ \\
\hline 5. & Total rainy days (days) & 281 & 280 \\
\hline \multicolumn{4}{|c|}{ C. Hydrology: } \\
\hline 6. & Inundation time (months) & $3-6$ & $<3$ \\
\hline 7. & Inundation height during the rainy season $(\mathrm{cm})$ & $(+)<10$ & (+) 21.92 \\
\hline 8. & Inundation height during the dry season $(\mathrm{cm}$ & (-) 20-50 & (-) 61,75 \\
\hline \multicolumn{4}{|c|}{ D. Soil: } \\
\hline 1. & $\mathrm{pH}$ & $4.4-5.8$ & $4.4-5.5$ \\
\hline 2. & C-organic (\%) & $0.98-2.04$ & $2.01-3.00$ \\
\hline 3. & Land Depth (cm) & $0-100$ & $0-60$ \\
\hline 4. & Salinity & No salinity & No salinity \\
\hline 5. & Texture & Clay, silty sand & silty clay; silty loam \\
\hline \multicolumn{4}{|c|}{ E. Plants: } \\
\hline 1. & Plant height at productive age (m) & 10.4 & - \\
\hline 2. & Average diameter $(\mathrm{cm})$ & 45.8 & 159.85 \\
\hline 3. & Estimated production (kg/Tree) & 162.4 & 560.89 \\
\hline
\end{tabular}

Note: Area I: Two villages in Bajo Barat Regency, Luwu Regency, South Sulawesi (Survey, 2018); Area II: Salubattang Village, Palopo City, South Sulawesi (Haeruddin, 2018). 
Table 3 - Land characteristics of sago plantations under dry and wet conditions in North Luwu Regency, South Sulawesi (Survey, 2018)

\begin{tabular}{|c|c|c|c|}
\hline No. & Land Characteristic & Dryland & Wetland \\
\hline \multicolumn{4}{|c|}{ A. Hydrology/Climate: } \\
\hline 1. & Average Rainfall (mm) & 2659 mm/year & 2659 mm/year \\
\hline 2. & Humidity (\%) & $77-84 \%$ & $77-84 \%$ \\
\hline 3. & Dry months (months) & $2-3$ months in a row & $2-3$ months in a row \\
\hline 4. & Wet months (months) & 7 - 8 months in a row & 7 - 8 months in a row \\
\hline 5. & Total of rainy days (days) & 282 rainy days in a year & 282 rainy days in a year \\
\hline 6. & Average temperature $\subset$ & $30^{\circ} \mathrm{C}$ & $35^{\circ} \mathrm{C}$ \\
\hline 7. & Solar radiation & $13.1-21.1$ (MJ m²/day) & $13.1-21.1\left(\mathrm{MJ} \mathrm{m}^{2} / \mathrm{day}\right)$ \\
\hline 8. & Sunshine (hours) & $3.6-7.5$ hours & $3.6-7.5$ hours \\
\hline 9. & Drainage & Very good & Bad - very bad \\
\hline 10. & Inundation height (water table) & (-) $60-100 \mathrm{~cm}$ (when it rains) & (+) $20-60 \mathrm{~cm}$ (3-6 month) \\
\hline \multicolumn{4}{|c|}{ B. Land and Soil: } \\
\hline 1. & Topography/slope & Ramps (8-10\%) & Flat $(0-3 \%)$ \\
\hline 2. & Rock material & $0-10 \%$ & $0 \%$ \\
\hline 3. & Root Depth & $0-80 \mathrm{~cm}$ & $0-60 \mathrm{~cm}$ \\
\hline 4. & $\mathrm{pH}$ & $5.1-6.6$ & $5.1-5.7$ \\
\hline 5. & C-Organic & $0.68-1.85 \%$ & $1.22-1.78 \%$ \\
\hline 6. & Salinity & $0.4-2.3 \mathrm{dS} / \mathrm{m}$ & $2,4 \mathrm{dS} / \mathrm{m}$ \\
\hline 7. & Bulk Density & $1.12-1.39 \mathrm{~g} / \mathrm{cm}^{3}$ & $1.02-1.02 \mathrm{~g} / \mathrm{cm}^{3}$ \\
\hline 8. & Water content & $0.23-0.45 \mathrm{~cm}^{\circ} / \mathrm{cm}^{\circ}$ & $0.33-0.51 \mathrm{~m}^{\circ} / \mathrm{cm}^{\circ}$ \\
\hline 9. & Texture & $\begin{array}{l}\text { Loam, clay loam, silty clay loam, sandy clay loam, loamy sand, } \\
\text { sandy loam, silty loam }\end{array}$ & $\begin{array}{l}\text { Silty clay loam, clay, silty clay, } \\
\text { clay loam }\end{array}$ \\
\hline & Soil color & brown, gray & Black, gray \\
\hline \multicolumn{4}{|c|}{ C. Sago Plant Conditions: } \\
\hline 1. & Number of tillers/seedlings & An average of $3-5$ trees & 8-10 trees \\
\hline 2. & Tree height ( 8 years old) & An average of 8 meters & 5 meters \\
\hline 3. & Rod diameter & $75 \mathrm{~cm}$ & $60 \mathrm{~cm}$ \\
\hline 4. & Average estimated production & $263.16 \mathrm{~kg}$ & $210.53 \mathrm{~kg}$ \\
\hline
\end{tabular}

Source: Primary data (survey in the Rongkong watershed, 2019).

Compilation results of sago growth requirements and sago land characteristics in the research location resulted in site-specific land suitability criteria (Table 4).

Table 4 - Site-specific land suitability criteria for sago (Metroxylon sp.)

\begin{tabular}{|c|c|c|c|c|c|c|}
\hline \multirow[t]{2}{*}{ No. } & \multirow{2}{*}{$\begin{array}{l}\text { Land Use Requirement/Land } \\
\text { Characteristic }\end{array}$} & \multicolumn{5}{|c|}{ Land suitability classes } \\
\hline & & S1 & S2 & S3 & $\mathrm{N}$ & \\
\hline \multicolumn{7}{|c|}{ A. Land Shape: } \\
\hline 1. & Elevation (m MSL) & $0-400$ & $401-600$ & $600-700$ & \multirow{2}{*}{\multicolumn{2}{|c|}{$\begin{array}{l}>700 \\
>35\end{array}$}} \\
\hline 2. & Slope (\%) & $0-8$ & $9-15$ & $16-35$ & & \\
\hline \multicolumn{7}{|c|}{ B. Climate: } \\
\hline 1. & Rainfall (mm year-1) & $2500-3500$ & $2001-2499 \& 3501-3750$ & $\begin{array}{l}1500-2000 \& \\
3751-4000\end{array}$ & \multicolumn{2}{|l|}{$\begin{array}{l}<1500 \& \\
>4000\end{array}$} \\
\hline 2. & Humidity (\%) & $77,0-90 \%$ & $58,5-76,5$ & $40,0-58,4$ & \multicolumn{2}{|l|}{$<40 \&>90$} \\
\hline 3. & Dry months (months) & & $2-3$ & $3-4$ & \multicolumn{2}{|c|}{$>4$} \\
\hline 4. & Wet months (month) & $8-9$ & $6-7$ & $3-5$ & \multirow{2}{*}{\multicolumn{2}{|c|}{$\begin{array}{l}<3 \\
<142 \&>282\end{array}$}} \\
\hline 5. & Rainy days (days) & $198-226$ & $\begin{array}{l}171-199 \& \\
227-253\end{array}$ & $\begin{array}{l}142-170 \& \\
254-282\end{array}$ & & \\
\hline 6. & Average temperature $(\mathrm{C})$ & $25-30$ & $20-25 \& 30-33$ & $15-20 \& 34-36$ & \multicolumn{2}{|c|}{$<15 \&>36$} \\
\hline 7. & Solar radiation $\left(\mathrm{MJ} \mathrm{m}^{2}\right.$ day $\left.^{-1}\right)$ & $16,3-17,9$ & $\begin{array}{l}14,7-16,2 \& \\
18,0-19,5\end{array}$ & $\begin{array}{l}13,1-14,6 \& \\
19,6-21,1\end{array}$ & \multicolumn{2}{|c|}{$\begin{array}{l}<13,1 \& \\
>21,1\end{array}$} \\
\hline 8. & Sunshine (hours) & $5,2-5,9$ & $\begin{array}{l}4,4-5,1 \& \\
6,0-6,7\end{array}$ & $\begin{array}{l}3,6-4,3 \& \\
6,8-7,5\end{array}$ & \multicolumn{2}{|c|}{$<3,6 \&>7,5$} \\
\hline \multicolumn{7}{|c|}{ C. Hydrology: } \\
\hline 1. & Inundation time (months) & & $3-6$ & $6-9$ & \multirow{3}{*}{\multicolumn{2}{|c|}{$\begin{array}{l}>9 \\
(+)>50 \mathrm{~cm} \\
(+)>10\end{array}$}} \\
\hline 2. & Inundation height $(\mathrm{cm})$ & $(+)<30$ & $(+) 30-50$ & $(+) 30-50 \mathrm{~cm}$ & & \\
\hline 3. & $\begin{array}{l}\text { Inundation height }(\mathrm{cm}) \text { in the dry } \\
\text { season }\end{array}$ & $(-) 60-80$ & $(-) 20-50$ & $(-) 10-(+) 10$ & & \\
\hline \multicolumn{7}{|c|}{ D. Soil Properties: } \\
\hline 1. & Rock material (\%) & $<10$ & $10-20$ & $21-30$ & \multirow{3}{*}{\multicolumn{2}{|c|}{$\begin{array}{l}>30 \\
0-<50 \\
<3,5 \&>6,6\end{array}$}} \\
\hline 2. & Root Depth (cm) & $0-100$ & $0-60$ & $0-50$ & & \\
\hline 3. & $\mathrm{pH}$ & $4,7-5,3$ & $\begin{array}{l}4,1-4,6 \& \\
5,3-5,9\end{array}$ & $\begin{array}{l}3,5-4,0 \& \\
6.0-6,6\end{array}$ & & \\
\hline 4. & C-Organic (\%) & $>1,50$ & $1,0-1,49$ & $0,50-0,99$ & \multirow{2}{*}{\multicolumn{2}{|c|}{$\begin{array}{l}<0,99 \\
>18,0\end{array}$}} \\
\hline 5. & Salinity (dS m-1) & $0-4,5$ & $4,5-9,0$ & $9,0-18,0$ & & \\
\hline 6. & Bulk Density (g cm-3) & $1,12-1,39$ & $\begin{array}{l}0,98-1,11 \& \\
1,40-1,53\end{array}$ & $\begin{array}{l}0,85-0,97 \& \\
1,54-1,67\end{array}$ & \multicolumn{2}{|c|}{$\begin{array}{l}<0,85 \quad \& \\
>1,67\end{array}$} \\
\hline 7. & Moisture content $(\mathrm{cm} \mathrm{cm}-3)$ & $0,34-0,45$ & $\begin{array}{l}0,23-0,33 \& \\
0,46-0,55\end{array}$ & $0,56-0,68$ & $\begin{array}{l}<0,23 \\
>0,68\end{array}$ & \& \\
\hline 8. & Texture & $\begin{array}{l}\text { Loam, clay Ic } \\
\text { sand, sandy }\end{array}$ & $\begin{array}{l}\text { clay loam, sandy clay loam, loamy } \\
\text { y loam. }\end{array}$ & Silt, clay, sand & - & \\
\hline
\end{tabular}

Note: the compilation of sago growth requirements (Bintoro, 2014; Leuhenapessy, 2012, \& Flach, 1997), with survey results of sago land characteristics in the location (2018). 
Sago growth requirements include climate, hydrology, land shape, and soil properties as can be seen in detail in Table 1. These growth requirements are determined by the Regulation of the Minister of Agriculture of the Republic of Indonesia Year 2014. These indicators serve as guidelines in gathering data on land characteristics in several sago plantations in South Sulawesi. The research area has the same ecosystem as the sago development plans (the Rongkong watershed). Climate and hydrological indicators include several parameters, i.e. rainfall, total rainy days, wet months, dry months, humidity, temperature, exposure time, solar radiation, sunshine, and drainage conditions. Land and soil characteristics include height, topography/slope, land cover, rock material, $\mathrm{pH}$ of root depth, C-organic, bulk density, soil moisture content, texture, and soil color (Tables 2 and 3). Rainfall is the only source of water in rainfed lands (Birhanu et al., 2018) which will determine the availability of groundwater (Al-Taai et al., 2014) for sago growth (Prathumyot et al., 2018; Okazaki et al., 2018). Hydrological conditions are also influenced by climate and meteorological factors, such as temperature (Porter et al., 2018), humidity (Uber et al., 2018), wind speed, solar radiation, and exposure time (Leomo et al., 2016; Forootan et al., 2019). These parameters influence water movement and plant metabolic processes (Qaderi et al., 2019).

Sago growing in the Rongkong watershed is the thornless type of sago known as "molat sago" (Metroxylon sago Rottb). The site-specific approach was performed by collecting data on land characteristics of sago plantations in South Sulawesi. Hydrological parameters become a priority in identifying sago plantations because hydrological parameters are directly related to climate characteristics (Wang et al., 2019), soil (Uddin et al., 2019), water availability for plants, and metabolic processes, especially plant nutrient absorption (Wan et al., 2019; Brotherton et al., 2019).

Sago palms grow in a fairly wide range of climatic conditions (Flach, 1996; Bintoro, 2008). Rainfall needed by sago palms (Table 1) according to Oldeman climate types includes the rather wet, wet, and very wet climate categories. These climate types are the same as the local sago plantation climate (Tables 2 and 3). The third characteristic of these parameters is an indication that sago requires quite a lot of water. Humidity presented in Table 1 shows a very high value in sago growth areas (40-90\%), while local sago areas (Tables 2 and 3 ) has a smaller value (77-84\%). Temperature needed by sago palms based on Flach $(1997)$ is lower and smaller $\left(15-29^{\circ} \mathrm{C}\right)$ when compared to the sago plantation conditions in the research location $\left(15-35^{\circ} \mathrm{C}\right)$. Differences in the characteristics of hydrological parameters between sago requirements in general and local sago plantations are caused by various types of sago. Similar results are obtained for the climate parameter. Sago at the research location is the thornless type of sago, whereas sago in general research object is the thorny type of sago (Metroxylon sago Rumphii).

Soil parameters influencing sago growth are $\mathrm{pH}$, C-organic, salinity, bulk density, moisture content, and texture. The effect of $\mathrm{pH}$ on sago growth is shown in plant responses in utilizing soil nutrients (Couto, 2018). The pHs at the observation location are acidic, slightly acidic, and neutral. Acidic conditions are ideal for optimal sago production (Okazaki and Sasaki, 2018) and influence the quality of sago starch (Lim et al., 2019). The C-organic content is also one of the important soil parameters for sago. The ideal C-Organic according to Bintoro et al., (2018) is $>18 \%$. However, in the C-organic condition of $2-3 \%$, local sago soil is still able to produce optimally. It is evidenced by the production of $560.89 \mathrm{~kg} / \mathrm{tree}$. The obstacle of agriculture today, especially lands located on the coast, is its salinity. Salinity stress causes damage to physiological functions of the root in absorbing nutrients for plants. However, this condition has no significant effect on sago if rainfall is high as in the research location. Salinity in the observation location is in the very low category (not a copy). Other soil parameters such as bulk density and texture influence water availability for plants. It is important because sago is expected not only to grow in wetlands but also in drylands. The importance of bulk density in increasing groundwater content is also confirmed by Xing et al. (2018). Other parameters for sago growth are soil conditions and soil properties (Okazaki et al., 2018; Bintoro et al., 2018; Ehara et al., 2018). Flach (1997) explains that sago can grow in various topographic conditions, ranging from flat, bumpy, to mountainous topography. 
Identification of land characteristics showed several parameters with the same values in the observation area (23 units) in the Salu Paku sub-watershed, the Rongkong watershed, North Luwu Regency. Data referred to are climatology and meteorology data such as rainfall (2889 mm/year), humidity (82\%), wet months (7-8 months), dry months (2-3 months), total of rainy days (282 per year), sunshine (5-6 hours), and solar radiation (13.1-21.1 $\mathrm{MJ} \mathrm{m}^{2}$ day $\left.^{-1}\right)$. Land characteristics have similar average value because they are in the same ecosystem. However, several land characteristics parameters have different values due to the influence of elevation and slope.

The overlay results of elevation and slope obtained 23 land units. Elevation and slope influence soil properties (Zinn et al., 2018). Slope and elevation influence plant growth and production (Nabiollahi et al., 2018; Wolka et al., 2018). The climate characteristics of the sago development plans are basically the same for all land units, i.e. the average annual rainfall of $2889 \mathrm{~mm} /$ year, longer wet months than dry months, high humidity, and sufficient solar radiation for metabolic processes. This similarity is caused by its location in the same ecosystem, i.e. the sub-watershed. The temperature parameters also show differences. Temperature tends to decrease by $1^{\circ} \mathrm{C}$ every time a change in elevation of 100 meters above sea level occurs. This condition shows a close relationship between elevation and temperature (Xu et al., 2015). Hydrology in the research land units indicates a good condition and not inundated. This condition is ideal for sago growth as long as the water in the soil is available for plant metabolic needs (Robbins and Dinneny, 2018; Meineke and Frank, 2018).

Different soil characteristics in some land units are root depth, C-organic content, and specific gravity. Some land units $(5,10,15)$ have a shallow root depth predicted to be a limiting factor for plant growth. Shallow soil in the land units is caused by steep and very steep slopes. This slope condition also has an impact on an increase in soil surface erosion processes (Tuo et al., 2018). Groundwater content is still possible to be improved according to sago needs by cutting the slope length to enable rainwater to enter the ground and become groundwater stock.

Table 5 - Land suitability analysis results for sago in 1 to 12 land units

\begin{tabular}{|c|c|c|c|c|c|c|c|c|c|c|c|c|c|}
\hline \multirow{2}{*}{ No. } & \multirow{2}{*}{$\begin{array}{c}\text { Land suitability/ } \\
\text { Land characteristic }\end{array}$} & \multicolumn{12}{|c|}{ Observation area/Land Unit } \\
\hline & & 1 & 2 & 3 & 4 & 5 & 6 & 7 & 8 & 9 & 10 & 11 & 12 \\
\hline A. & Hydrology/Climate: & & & & & & & & & & & & \\
\hline 1. & Rainfall & S1 & S1 & S1 & S1 & S1 & S1 & S1 & S1 & S1 & S1 & S1 & S1 \\
\hline 2. & Humidity & S1 & $\mathrm{S} 1$ & S1 & S1 & S1 & S1 & $\mathrm{S} 1$ & S1 & S1 & S1 & S1 & $\mathrm{S} 1$ \\
\hline 3. & Total Wet Months & S1 & S1 & S1 & S1 & S1 & S1 & S1 & s1 & S1 & S1 & S1 & S1 \\
\hline 4. & Total Dry Months & S1 & S1 & S1 & S1 & S1 & S1 & S1 & S1 & S1 & S1 & S1 & S1 \\
\hline 5. & Total Rainy Days & S1 & S1 & S1 & S1 & S1 & S1 & S1 & S1 & S1 & S1 & S1 & S1 \\
\hline 6. & Average temperature & S1 & S1 & S1 & S1 & S1 & S1 & S1 & S1 & S2 & S2 & S2 & S2 \\
\hline 7. & Sunshine & S1 & $\mathrm{S} 1$ & S1 & S1 & S1 & S1 & $\mathrm{S} 1$ & $\mathrm{~S} 1$ & S1 & $\mathrm{S} 1$ & S1 & S1 \\
\hline 8. & Solar Radiation & S1 & S1 & S1 & S1 & S1 & S1 & S1 & S1 & S1 & S1 & S1 & S1 \\
\hline 9. & Drainage & S1 & $\mathrm{S} 1$ & S1 & S1 & $\mathrm{S} 1$ & S1 & $\mathrm{S} 1$ & $\mathrm{~S} 1$ & S1 & S1 & S1 & $\mathrm{S} 1$ \\
\hline B. & Land/Soil Properties: & & & & & & & & & & & & \\
\hline 1. & Land Use & S1 & S1 & S1 & S1 & S1 & S1 & S1 & $\mathrm{S} 1$ & S1 & S1 & S1 & S1 \\
\hline 2. & Topography/Slope & S1 & S1 & S2 & S3 & $\mathrm{N}$ & S1 & S1 & S2 & S3 & $\mathrm{N}$ & S1 & S1 \\
\hline 3. & Rock material & S1 & s1 & s1 & S1 & S1 & S1 & S1 & s1 & S1 & S1 & S1 & S1 \\
\hline 4. & Root depth & S1 & S1 & S2 & S2 & $\mathrm{N}$ & S1 & S1 & $\mathrm{S} 2$ & S2 & $\mathrm{N}$ & s1 & S1 \\
\hline 5. & $\mathrm{pH}$ & S1 & S1 & S1 & S1 & S1 & S1 & S1 & $\mathrm{s} 1$ & S1 & S1 & s1 & S1 \\
\hline 6. & Salinity & S1 & S1 & S1 & S1 & S1 & S1 & S1 & S1 & S1 & S1 & S1 & S1 \\
\hline 7. & C-Organic & S1 & S1 & S1 & S2 & S2 & S1 & S1 & S1 & S2 & S2 & S1 & S1 \\
\hline 8. & Bulk Density & S1 & S1 & S1 & S2 & S2 & S1 & S1 & S1 & S2 & S2 & S1 & S1 \\
\hline 9. & Groundwater content & S2 & S2 & S2 & $\mathrm{N}$ & $\mathrm{N}$ & S2 & $\mathrm{s} 2$ & s2 & $\mathrm{N}$ & $\mathrm{N}$ & S2 & S2 \\
\hline 10. & Texture & S1 & S1 & S1 & S1 & S1 & S1 & S1 & S1 & S1 & S1 & S1 & S1 \\
\hline 11. & Soil color & S1 & S1 & S1 & S1 & S1 & S1 & S1 & S1 & S1 & S1 & S1 & S1 \\
\hline & Actual Suitability & S2 & $\mathrm{S} 2$ & S2 & $\mathrm{N}$ & $\mathrm{N}$ & S2 & $\mathrm{S} 2$ & S2 & $\mathrm{N}$ & $\mathrm{N}$ & S2 & S2 \\
\hline & Potential Suitability & S1 & $\mathrm{S} 1$ & S2 & S2 & $\mathrm{N}$ & S1 & S1 & S2 & S2 & $\mathrm{N}$ & S2 & $\mathrm{S} 2$ \\
\hline
\end{tabular}

Land suitability analysis results for sago in the Salu Paku sub-watershed, the Rongkong watershed are presented in Tables 5 and 6. Land suitability analysis results in actual and potential land suitability classes. Based on analysis results, locations of sago development plans showed the actual suitability of a Moderately suitable (S2) area of $1,889.61$ ha and a Not Suitable $(\mathrm{N})$ area of 440.24 ha. These values are still possible to be 
increased to potential suitability, i.e. S2 to $\mathrm{S} 1$ and $\mathrm{N}$ to $\mathrm{S} 2$. Opportunities for changes in land suitability are found in 1, 2, 6, and 7 land units covering an area of 116.95 ha. A change from Not Suitable $(\mathrm{N})$ to $\mathrm{S} 2$ is possible in 4, 9, 14, 19, and 23 land units covering an area of 437.89 ha. An input that can be given to change the suitability class is to increase groundwater content through soil surface improvement which can encourage an increase in rainwater infiltration processes (Luna et al., 2018). Some actions that can be taken include making a reservoir and dead-end trenches on flat and gently sloping land. On the sloping land, terraces can be made. Efforts to improve soil water content are predicted to be able to support sago growth and productivity due to optimal soil conditions for photosynthesis (Azhar et al., 2018) and to improve starch quality (Ming, 2018).

Table 6 - Land suitability analysis results for sago in 13 to 23 land units

\begin{tabular}{|c|c|c|c|c|c|c|c|c|c|c|c|c|}
\hline \multirow{2}{*}{ No. } & \multirow{2}{*}{$\begin{array}{c}\text { Land suitability/ } \\
\text { Land characteristic }\end{array}$} & \multicolumn{11}{|c|}{ Observation area/Land Unit } \\
\hline & & 13 & 14 & 15 & 16 & 17 & 18 & 19 & 20 & 21 & 22 & 23 \\
\hline A. & Hydrology/Climate: & & & & & & & & & & & \\
\hline 1. & Rainfall & S1 & $\mathrm{S} 1$ & S1 & S1 & S1 & S1 & S1 & S1 & S1 & S1 & S1 \\
\hline 2. & Humidity & S1 & S1 & S1 & S1 & S1 & S1 & S1 & S1 & S1 & S1 & S1 \\
\hline 3. & Total Wet Months & S1 & S1 & S1 & S1 & S1 & S1 & S1 & S1 & S1 & S1 & S1 \\
\hline 4. & Total Dry Months & S1 & S1 & S1 & S1 & S1 & S1 & S1 & S1 & S1 & S1 & S1 \\
\hline 5. & Total Rainy Days & $\mathrm{S} 1$ & S1 & S1 & S1 & S1 & S1 & S1 & S1 & S1 & S1 & S1 \\
\hline 6. & Average temperature & S2 & S2 & S2 & S2 & S2 & S2 & S2 & S2 & S2 & S2 & S2 \\
\hline 7. & Sunshine & S1 & S1 & S1 & S1 & S1 & S1 & S1 & S1 & S1 & S1 & S1 \\
\hline 8. & Solar Radiation & S1 & S1 & S1 & S1 & S1 & S1 & S1 & S1 & S1 & S1 & S1 \\
\hline 9. & Drainage & S1 & S1 & S1 & S1 & S1 & S1 & S1 & S1 & S1 & S1 & S1 \\
\hline B. & Land/Soil Properties: & & & & & & & & & & & \\
\hline 1. & Land Use & S1 & S1 & S1 & S1 & S1 & S1 & S1 & S1 & S1 & S1 & S1 \\
\hline 2. & Topography/Slope & S2 & S3 & $\mathrm{N}$ & S1 & S1 & S2 & S3 & S1 & S1 & S2 & S3 \\
\hline 3. & Rock material & $\mathrm{S} 1$ & S1 & S1 & S1 & S1 & S1 & S1 & S1 & S1 & S1 & S1 \\
\hline 4. & Root depth & S2 & S2 & $\mathrm{N}$ & S1 & S1 & S2 & S2 & S1 & S1 & S2 & S2 \\
\hline 5. & $\mathrm{pH}$ & $\mathrm{S} 1$ & S1 & S1 & S1 & S1 & S1 & S1 & S1 & S1 & S1 & S1 \\
\hline 6. & Salinity & $\mathrm{S} 1$ & S1 & S1 & S1 & S1 & S1 & S1 & S1 & S1 & S1 & S1 \\
\hline 7. & C-Organic & S1 & S2 & S2 & S1 & S1 & S1 & S2 & S1 & S1 & S1 & S2 \\
\hline 8. & Bulk Density & S1 & S2 & S2 & S1 & S1 & S1 & S2 & S1 & S1 & S1 & S2 \\
\hline 9. & Groundwater content & S2 & $\mathrm{N}$ & $\mathrm{N}$ & S2 & S2 & S2 & $\mathrm{N}$ & S2 & S2 & S2 & $\mathrm{N}$ \\
\hline 10. & Texture & S1 & S1 & S1 & S1 & S1 & S1 & S1 & S1 & S1 & S1 & S1 \\
\hline \multirow[t]{3}{*}{11.} & Soil color & S1 & S1 & S1 & S1 & S1 & S1 & S1 & S1 & S1 & S1 & S1 \\
\hline & Actual Suitability & $\mathrm{S} 2$ & $\mathrm{~N}$ & $\mathrm{~N}$ & S2 & S2 & S2 & $\mathrm{N}$ & S2 & S2 & S2 & $\mathrm{N}$ \\
\hline & Potential Suitability & S2 & S2 & $\mathrm{N}$ & S2 & S2 & S2 & S2 & S2 & S2 & S2 & S2 \\
\hline
\end{tabular}

Source: Processed primary data, 2019.

Actions to increase water absorption into the soil as a strategy to improve the condition of sago plantations in rainfed drylands also have an impact on improving watershed hydrology. As confirmed by Morbidelli et al. (2018), an increase in water infiltration will automatically reduce surface runoff and further stabilize river water discharges. Reducing water discharges through upstream water regulation can be a solution for downstream flooding (Keesstra et al., 2018).

\section{CONCLUSION}

Land characteristics of local sago plantations compiled with sago growth requirements in general produce site-specific suitability criteria and serve as a guide in assessing sago land suitability classes in the locations of sago development plans. The actual land suitability classes showed a moderately suitable (S2) area of 1,889.61 ha and a Not Suitable (N) area of $440.24 \mathrm{ha}$. The limiting factor for S2 lands is groundwater content, while the limiting factors for not suitable $(\mathrm{N})$ lands are groundwater content, slope, root depth, and temperature. Some land units have a potential suitability class of Class S1 after receiving an input to improve groundwater content. Class $\mathrm{N}$ (not suitable) can be upgraded to Class S2 by improving groundwater content. Increased groundwater content can be increased by managing surface soil which can encourage increased infiltration capacity through the manufacture of water bags such as dead-end trenches for flatlands and terraces for sloping lands. 


\section{ACKNOWLEDGMENTS}

The authors would like to thank the Faculty of Agriculture, University of Brawijaya, as the organizer of the Agricultural Science Doctoral Program, in which we continue our studies. The authors also thank the Ministry of Research, Technology, and Higher Education of the Republic of Indonesia through the Postgraduate Domestic Education Scholarship Program for financial support.

\section{REFERENCES}

1. Abaker, W. E., F. Berninger, M. Starr, 2018. Changes in soil hydraulic properties, soil moisture and water balance in Acacia senegal plantations of varying age in Sudan. Journal of Arid Environments, 150, 42-53. https://doi.org/10.1016/j.jaridenv.2017.12.004.

2. Ahmad, M. (2014). Farmer empowerment to increase productivity of sago (Metroxylon sago spp) farming. International Journal on Advanced Science, Engineering and Information Technology, 4(3), 129-133. DOI: http://dx.doi.org/10.18517/ijaseit.4.3.384.

3. Al-Taai, O. T., Ahmed, M. M., \& Jawad, T. K. (2014). Influence of rainfall on soil water content in Iraq. Int. J. Agric. Innov. Res, 3, 618-627.

4. Azhar, A., Makihara, D., Naito, H., \& Ehara, H. (2018). Photosynthesis of Sago Palm (Metroxylon sagu Rottb.) Seedling at Different Air Temperatures. Agriculture, 8(1), 4. https://doi.org/10.3390/agriculture8010004.

5. Azhar, A., Makihara, D., Naito, H., \& Ehara, H. (2018). Evaluating sago palm (Metroxylon sagu Rottb.) photosynthetic performance in waterlogged conditions: utilizing pulseamplitude-modulated (PAM) fluorometry as a waterlogging stress indicator. Journal of the Saudi Society of Agricultural Sciences. https://doi.org/10.1016/j.jssas.2018.05.004.

6. Berners-Lee, M., Kennelly, C., Watson, R., \& Hewitt, C. N., 2018. Current global food production is sufficient to meet human nutritional needs in 2050 provided there is radical societal adaptation. Elem Sci Anth, 6(1). http://doi.org/10.1525/elementa.310.

Bintoro, M. A. H. M. H. (2008). Bercocok tanam sagu. Institut Pertanian Bogor.

7. Bintoro, M. H., Nurulhaq, M. I., Pratama, A. J., Ahmad, F., \& Ayulia, L., 2018. Growing area of sago palm and its environment. In Sago Palm (pp. 17-29). Springer, Singapore.

8. Birhanu, B. Z., K. Traoré, M.K. Gumma, F. Badolo, R. Tabo, \& A.M. Whitbread, 2018. A watershed approach to managing rainfed agriculture in the semiarid region of southern Mali: integrated research on water and land use. Environment, Development and Sustainability, 1-27. https://link.springer.com/article/10.1007/s10668-018-0144-9.

9. Botanri, S., Setiadi, D., Guhardja, E., Qayim, I., and L. B. Prasetyo, 2011. Karakteristik habitat tumbuhan sagu (Metroxylon spp.) di pulau Seram, Maluku. In Forum Pascasarjana (Vol. 34, No. 1, pp. 33-44).

10. Brotherton, S. J., Joyce, C. B., Berg, M. J., \& Awcock, G. J. (2019). Immediate and lag effects of hydrological change on floodplain grassland plants. Plant Ecology, 220(3), 345359.

11. Budianto, J. (2003, October). Teknologi sagu bagi agribisnis and ketahanan pangan. In Prosiding Seminar Nasional, Sagu Untuk Ketahanan Pangan. Manado (Vol. 6, pp. 5-15).

12. BPT, 2005. Analisis kimia tanah, tanaman, air and pupuk. Badan penelitian and Pengembangan Pertanian Departemen Pertanian, Bogor, Indonesia, 1, 44-45.

13. Couto, W. (2018). Soil pH and plant productivity. In Handbook of agricultural productivity (pp. 71-84). CRC Press.

14. Ehara, H., 2005. Geographycal distributon and specification of Metroxylon palms Jpn. J. Trop. Agr., 50 (2005), pp. 229-233.

15. FAO. Soils resources, management and conservation service. (1983). Guidelines: land evaluation for rainfed agriculture. FAO.

16. Flach, M. (1997). Sago palm: Metroxylon sagu Rottb. Promoting the conservation and use of underutilized and neglected crops. 13. Bioversity International. 
17. Flach, M., and D.L., Schuiling, 1991. Growth and yield of sago palms in relation to their nutritional needs [Sarawak]. In 4. International Sago Symposium, Kuching, Sarawak (Malaysia), 6-9 Aug 1990. Ministry of Agriculture and Community Development

18. Forootan, E. (2019). Analysis of trends of hydrologic and climatic variables. Soil and Water Research, 14(3), 163-171. https://doi.org/10.17221/154/2018-SWR.

19. Gedefaw, M., Wang, H., Yan, D., Song, X., Yan, D., Dong, G., ... \& Abiyu, A. (2018). Trend analysis of climatic and hydrological variables in the Awash River Basin, Ethiopia. Water, 10(11), 1554.

20. Gerland, P., Raftery, A. E., Ševčíková, H., Li, N., Gu, D., Spoorenberg, T., ... \& Bay, G. (2014). World population stabilization unlikely this century. Science, 346(6206), 234-237. DOI: $10.1126 /$ science.1257469.

21. Girmay, G., Sebnie, W., \& Reda, Y. (2018). Land capability classification and suitability assessment for selected crops in Gateno watershed, Ethiopia. Cogent Food \& Agriculture, 4(1), 1532863.

22. Girsang, W. 2018. Feasibility of Small-Scale Sago Industries in the Maluku Islands, Indonesia. In Sago Palm (pp. 109-121). Springer, Singapore.

23. Henry, R. C., Engström, K., Olin, S., Alexander, P., Arneth, A., \& Rounsevell, M. D. A. (2018). Food supply and bioenergy production within the global cropland planetary boundary. PloS one, 13(3), e0194695.https://doi.org/10.1371/journal.pone.0194695.

24. Keesstra, S., Nunes, J., Novara, A., Finger, D., Avelar, D., Kalantari, Z., \& Cerdà, A. (2018). The superior effect of nature based solutions in land management for enhancing ecosystem services. Science of the Total Environment, 610, 997-1009.

25. Konuma, H., 2018. Status and Outlook of Global Food Security and the Role of Underutilized Food Resources: Sago Palm. In Sago Palm (pp. 3-16). Springer, Singapore.

26. Kurnia, D., 2017. Startegi Pengembangan Adroindustri Sagu Kab. Indragiri Hilir Riau. Selodang Mayang, 3(3).

27. Leomo, S., Jaya, M., \& Arli, W. O. (2016). The effect of elevation gradient on the phenological aspect of growth and production of sago palm (Metroxylon sagu Rottb.). Advances in Environmental Biology, 10(3), 28-35.

28. Lim, L. W. K., Chung, H. H., Hussain, H., \& Bujang, K. (2019). Sago Palm (Metroxylon sagu Rottb.): Now and Beyond. Pertanika Journal of Tropical Agricultural Science, 42(2).

29. Liu, Y., Xin, Y., Xie, Y., \& Wang, W. (2019). Effects of slope and rainfall intensity on runoff and soil erosion from furrow diking under simulated rainfall. Catena, 177, 92-100.

30. Louhenapessy, and J. Elseos, 1996. Evolusi and klasifikasi kesesuaian lahan bagi sagu (Metroxylon Spp.). Gadjah Mada University. Yogyakarta.

31. Luna, L., Vignozzi, N., Miralles, I., \& Solé-Benet, A. (2018). Organic amendments and mulches modify soil porosity and infiltration in semiarid mine soils. Land degradation \& development, 29(4), 1019-1030.

32. Manaroinsong, E., Maliangkay, R. B., and N. Mashud, 2018. Budidaya Tanaman Sagu (Metroxylon sp.) di Lahan Pasang Surut. Buletin Palma, (34).

33. McClatchey W, Harley IM, and R.E. Craig, 2006. Metroxylon amicarium, M. paulcoxii, M. sagu, M. salomonense, M. vitiense, and M. warburgii (sago palms). In: Elevitch CR (ed). Traditional Trees of Pacific Islands: their culture, environment, and use. Permanent Agricultural Resources, Holualoa, Hawai'i.

34. Meineke, E. K., \& Frank, S. D. (2018). Water availability drives urban tree growth responses to herbivory and warming. Journal of applied ecology, 55(4), 1701-1713.

35. Mofu, W. Y., \& Rahawarin, J. Soenarto. 2005. The growth of sago palm in Kaureh District, Jayapura, Papua. In Eight International Sago Symposium in Jayapura, Indonesia. Japan Society for the Promotion Science.

36. Morbidelli, R., Saltalippi, C., Flammini, A., \& Govindaraju, R. S. (2018). Role of slope on infiltration: a review. Journal of hydrology, 557, 878-886.

37. Nabiollahi, K., Golmohamadi, F., Taghizadeh-Mehrjardi, R., Kerry, R., \& Davari, M. (2018). Assessing the effects of slope gradient and land use change on soil quality 
degradation through digital mapping of soil quality indices and soil loss rate. Geoderma, 318, 16-28.

38. Okazaki, M., \& Sasaki, Y. (2018). Soil Environment in Sago Palm Forest. In Sago Palm (pp. 193-206). Springer, Singapore.

39. Pijl, A., Brauer, C. C., Sofia, G., Teuling, A. J., \& Tarolli, P. (2018). Hydrologic impacts of changing land use and climate in the Veneto lowlands of Italy. Anthropocene, 22, 20-30.

40. Porter, J. M., \& Schramm Jr, H. L. (2018). Effects of temperature and hydrology on growth of shovelnose sturgeon Scaphirhynchus platorynchus (Rafinesque, 1820) in the lower Mississippi River. Journal of applied ichthyology, 34(1), 21-28.

41. Prathumyot, W., Chitaree, L., Chakhatrakan, S., Romkaew, J., Waramit, N., Matta, F. B., \& Ehara, H. (2018). Responses of sago palm under water deficiency condition. International Journal of Agricultural Technology, 14(7 Special Issue), 1679-1684.

42. Prosekov, AY, \& Ivanova, SA (2018). Keamanan pangan: Tantangan masa kini. Geoforum , 91, 73-77.

43. Qaderi, M. M., Martel, A. B., \& Dixon, S. L. (2019). Environmental factors influence plant vascular system and water regulation. Plants, 8(3), 65.

44. Robbins, N. E., \& Dinneny, J. R. (2018). Growth is required for perception of water availability to pattern root branches in plants. Proceedings of the National Academy of Sciences, 115(4), E822-E831.

45. Rossiter, D. G. (1996). A theoretical framework for land evaluation. Geoderma, 72(3-4), 165-190.

46. Sajedi-Hosseini, F., Choubin, B., Solaimani, K., Cerdà, A., \& Kavian, A. (2018). Spatial prediction of soil erosion susceptibility using a fuzzy analytical network process: Application of the fuzzy decision making trial and evaluation laboratory approach. Land degradation \& development, 29(9), 3092-3103.

47. Singhal, R. S., Kennedy, J. F., Gopalakrishnan, S. M., Kaczmarek, A., Knill, C. J., \& Akmar, P. F. (2008). Industrial production, processing, and utilization of sago palm$\begin{array}{llll}\text { derived products. } & \text { Carbohydrate }\end{array}$ https://doi.org/10.1016/j.carbpol.2007.07.043.

48. Suyastri, C., Marhadi, M., \& Yudilla, A. (2018, November). Hedging Local Products: Optimizing The Processed Products of Sago Commodity to Become More Competitive Globally. In PROCEEDINGS INTERNATIONAL CONFERENCE BKSPTIS 2018.

49. Tomlinson, I. (2013). Doubling food production to feed the 9 billion: a critical perspective on a key discourse of food security in the UK. Journal of rural studies, 29, 81-90. https://doi.org/10.1016/j.jrurstud.2011.09.001.

50. Tuo, D., Xu, M., \& Gao, G. (2018). Relative contributions of wind and water erosion to total soil loss and its effect on soil properties in sloping croplands of the Chinese Loess Plateau. Science of the Total Environment, 633, 1032-1040.

51. Uber, M., Vandervaere, J. P., Zin, I., Braud, I., Heisterman, M., Legoût, C., ... \& Nord, G. (2018). How does initial soil moisture influence the hydrological response? A case study from southern France. Hydrology and Earth System Sciences, 22, 6127-6146.

Uddin, M. J., Hooda, P. S., Mohiuddin, A. S. M., Smith, M., \& Waller, M. (2019). Land inundation and cropping intensity influences on organic carbon in the agricultural soils of Bangladesh. Catena, 178, 11-19.

52. Vu, J. C., \& Yelenosky, G. (1991). Photosynthetic responses of citrus trees to soil flooding. Physiologia Plantarum, 81(1), 7-14.

53. Wan, Y., Huang, Q., Camara, A. Y., Wang, Q., \& Li, H. (2019). Water management impacts on the solubility of $\mathrm{Cd}, \mathrm{Pb}, \mathrm{As}$, and $\mathrm{Cr}$ and their uptake by rice in two contaminated paddy soils. Chemosphere, 228, 360-369.

54. Wang, H., Tetzlaff, D., Buttle, J., Carey, S. K., Laudon, H., McNamara, J. P., ... \& Soulsby, C. (2019). Climate-phenology-hydrology interactions in northern high latitudes: Assessing the value of remote sensing data in catchment ecohydrological studies. Science of the Total Environment, 656, 19-28. 
55. Wolka, K., Mulder, J., \& Biazin, B. (2018). Efek teknik konservasi tanah and air terhadap hasil panen, limpasan and hilangnya tanah di Afrika Sub-Sahara: tinjauan. Manajemen air pertanian, 207, 67-79.

56. Xing, X., Li, Y., \& Ma, X. (2018). Koreksi kurva retensi air menggunakan perubahan dalam kepadatan curah selama pengumpulan data. Rekayasa Geologi , 233 , 231-237.

57. Xu, M., Wang, G., Li, X., Cai, X., Li, X., Christie, P., \& Zhang, J. (2015). The key factor limiting plant growth in cold and humid alpine areas also plays a dominant role in plant carbon isotope discrimination. Frontiers in plant science, 6, 961.

58. Yamamoto, Y. (2018). Outcomes and Recommendations from the 12th International Sago Symposium. In Sago Palm (pp. 319-330). Springer, Singapore.

59. Zinn, Y. L., Andrade, A. B., Araujo, M. A., \& Lal, R. (2018). Soil organic carbon retention more affected by altitude than texture in a forested mountain range in Brazil. Soil Research, 56(3), 284-295. 